\title{
DETERMINATION OF ARSENIC IN TUUL RIVER AND IN DRINKING WATER, USING HG-AAS WITH ELECTRICALLY HEATED ATOMIZER
}

\author{
T.Tsetsegmaa ${ }^{1}$,Ts. Darjaa ${ }^{2}$ \& D.Dorj ${ }^{3}$ \\ Actlabs Asia Laboratory in Ulaanbaata \\ ${ }^{2,3}$ National University of Mongolia, Faculty of Chemistry
}

\begin{abstract}
:
The electrothermal atomizer was installed in a Varian AA240FS AAS. This equipment was tested for determination of arsenic by hydride generation - atomic absorption method in water samples in the low $\mu \mathrm{g} / \mathrm{l}$ range. Pre-reduction capability of KI investigated systematically and obtained as $2.5 \%$. Analytical parameters, that influencing for hydride formation $\mathrm{NaBH}_{4}$ and $\mathrm{HCl}$ concentrations are optimized and employed as $0.5 \%$ and 8 $\mathrm{mol} / \mathrm{l}$ accordingly.

The detection limit for determination of arsenic by optimized HG-AAS with electrically heated atomizer was $0.3 \mu \mathrm{g} / \mathrm{l}$. The accuracy is confirmed by optimized HG-AAS method with flame atomizer and by ICP-MS.

Water samples were taken from the different places of Tuul river and from groundwater in the same area. It was found that the arsenic concentration in the river was low, around $3 \mathrm{ppb}$. The concentration of arsenic in groundwater was around the detection limit of method and no detectable amount of arsenic was found in the other. Concentration of arsenic in the Tuul river in these districts does not seem to be so high that it could affect the people living there.
\end{abstract}

\section{KEYWORDS:}

Arsenic and arsenic speciation; Hydride Generation Atomic Absorption Spectrometry HG-AAS; oven, Tuul river water; Mongolia.

\section{INTRODUCTION}

Arsenic is among the top 20 most toxic substances in the world and can lead to wide range of health problems in humans. Their concentrations in the environment vary, partly in relation to geology and partly as a result of human activities. Living organisms are exposed to the toxic arsenic species from food and water. The contamination of groundwater with arsenic has already been reported in 20 countries, out of which four major instances are from Asia: Bangladesh, India, Taiwan and Inner Mongolia [1]

The mobility and toxicity of arsenic are determined by its oxidation state, thus the 
behaviour of arsenic species will change depending on the biotic and abiotic conditions in water. In groundwater, arsenic is predominantly present as As (III) and As (V), with a minor amount of methyl and dimethylarsenic compounds [1]. The concentration of arsenic in most groundwater is $<10 \mu \mathrm{g} / 1$ and often below the detection limit of routine analytical methods.

Concentration of arsenic in river waters are also low, typically in the range 0.1-2.0 $\mu \mathrm{g} / \mathrm{l}$. Relatively high concentrations of naturally occuring arsenic in rivers can occur as a result of geothermal activity or the influx of high - arsenic groundwaters [2].

People living in UB are depending on the water from the Tuul river and from the deep water wells in the area. The level of arsenic in the water must be monitored and won't exceed the guidelines. It is impossible to know if drinking water contains arsenic without doing measurements since arsenic is tasteless colorless and without smell [3]. To detect low concentration of arsenic in water samples sensitive methods such as, hydride generation technique linked with AAS widely used. Almost in HG system for atomization of arsine gases quartz tube heated by air - acetylene flame. The flame temperature is an important parameter governing the flame process. The gases from the flame interferes with the light beam and decreases its intensity and increases background signal, especially in the ultraviolet range, which is used for determination of As. To control the flame temperature we tested electrically heated atomizer with temperature controller. This will give more stable results and lower detection limit.

The purpose of this study was to optimize and improve a method that was used for determining arsenic at the low ppb level in water samples and determine concentration of arsenic in Tuul river.

\section{EXPERIMENTAL}

Sampling

The samples were collected in October from the selected places of Tuul river in Ulaanbaatar. Collected samples shown in Table 1. There were taken from East part of UB - Gachuurt district, Central part - Zaisan district, West part - Factory district. Two samples were taken from deep drilled well used for drinking water. All samples were collected in $100 \mathrm{ml}$ polyethylene flasks and acidified with $1 \mathrm{ml}$ hydrochloric acid in laboratory to preserve trace metals.

Table 1. The sampling location

\begin{tabular}{ll}
\hline Sample & Location \\
\hline Sample 1 & Gachuurt district \\
Sample 2 & Zaisan district \\
Sample 3 & Factory district \\
DW 1 & Deep well from Central part of UB \\
DW 2 & Deep well from North part of UB \\
TW & Tap water from Factory district \\
\hline
\end{tabular}


Sample analysis

For the determination of arsenic by vapor generator, $5 \mathrm{ml}$ of water sample solution was transferred into test tube, $1 \mathrm{ml} 25 \%$ potassium iodide/ascorbic acid reductant was added and the volume was diluted to $10 \mathrm{ml}$ with dionized water. Arsenic concentration was determined by HG-AAS at $193.7 \mathrm{~nm}$ wavelength with optimized conditions, given in Table 2. Sample solution uptake rates were within the range $6.0-6.3 \mathrm{ml} / \mathrm{min}$, the acid and reductant solution uptake rates were $0.8-1.0 \mathrm{ml} / \mathrm{min}$.

Table 2. Optimized operating conditions for HG-AAS

$\begin{array}{ll}\text { Concentration } \mathrm{NaBH} 4 \text { solution } & 0.5 \% \\ \text { Concentration } \mathrm{HCl} & 8 \mathrm{M} \\ \text { Measurement time } & 5 \mathrm{sec} \\ \text { Read delay } & 45 \mathrm{sec}\end{array}$

Instrumenal parameters

Spectrometer

Wavelength

$193.7 \mathrm{~nm}$

Slit width

AA240FS

Lamp current

$0.5 \mathrm{R}$

Signal recording mode Peak area

Series of sample was analysed two different days. Each sample was measured 3 replicates. Blank sample was measured and subtracted from the results.

All samples were measured by HG-AAS method, using air-acetylene flame atomizer and by optimized HG-AAS method, using electrically heated atomizer. HG-AAS with flame atomizer method was optimized and cheked by other methods and certified standard reference materials [4]. These optimized parameters were used for determination of arsenic in water samples by HG-AAS with flame.

\section{Instrument optimization}

Atomic absorption spectrophotometer Varian Model AA240FS was equipped Varian Model VGA-77 hydride generation system with electrically heated atomizer ETC-60 (Picture 1). The most important parameters such as temperature of furnace, concentrations of reductant, pre - reductant and acid were optimized.

Temperature optimization. The ETC-60 atomizer consists of a Temperature Control Module and a workhead containing a quartz absorption tube. Manufacturer recommended temperatures range is between ambient to $999^{\circ} \mathrm{C}$. Standard solutions $2 \mu \mathrm{g} / \mathrm{l}, 10 \mu \mathrm{g} / \mathrm{l} \mathrm{As}$ and blank solutions were tested with temperatures $820,850,870,900,925,950^{\circ} \mathrm{C}$ to get maximum signal response. Signal intensity has increased with increasing the temperature 
up to $870^{\circ} \mathrm{C}$, when slightly decreased. Therefore, the temperature of the oven was set to $870^{\circ} \mathrm{C}$ for atomization of arsenic.

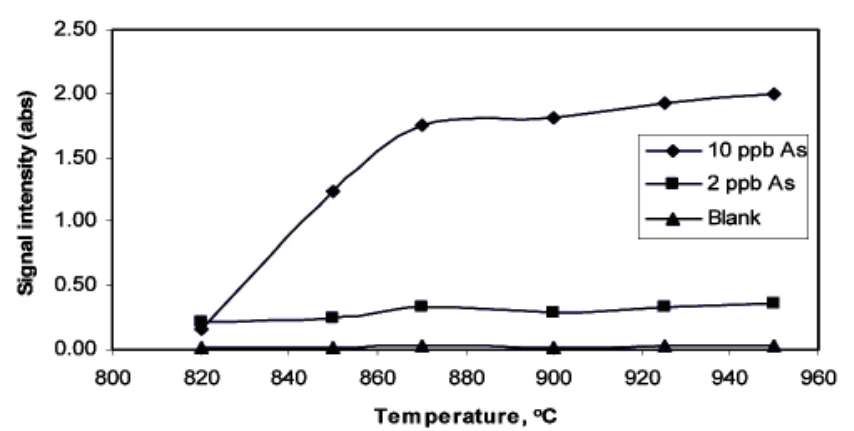

Fig. 1. Influence of temperature on signal intensity of As standard solution.

Hydride forming parameters: hydrochloric acid and sodium tetrahydroborate concentrations. Signal intensity of $2 \mu \mathrm{g} / \mathrm{l}$ As solution was investigated in the range $2-10 \mathrm{~mol} / \mathrm{l}$ $\mathrm{HCl}(2 ; 4 ; 5 ; 7 ; 8 ; 10 \mathrm{~mol} / \mathrm{l} \mathrm{HCl})$. During the test absorption signal of As standard solution increased with increasing of acid concentration and reached a maximum at $8 \mathrm{~mol} / \mathrm{l}$, as shown in Fig. 2. Therefore, $8 \mathrm{~mol} / 1 \mathrm{HCl}$ concentration was chosen for further investigations. Also the blank solution was investigated and it gave stable signal with different concentration of hydrochloric acid.

Sodium tetrahydroborate concentration in the range $0.01-2 \%(0.1 ; 0.3 ; 0.5 ; 0.7 ; 0.9$; $1.0 ; 1.3 ; 1.5 ; 1.7 ; 1.9 ; 2.0 \%) \mathrm{NaBH}_{4}$ was optimized by $2 \mu \mathrm{g} / 1$ As standard solution. The signal is increased with the increasing the sodium tetrahydroborate concentration. Optimization with concentrations of $0.1-2 \% \mathrm{NaBH}_{4}$ shows, that signal intensity increases and become stable up to $1.0 \% \mathrm{NaBH}_{4}$. Then it starts to give unstable signal and signal of blank solution is increased as shown in Fig. 3. It's important to get stable signal with low signal of blank solution. From this point of view $0.5 \% \mathrm{NaBH}_{4}$ was chosen for future investigations.

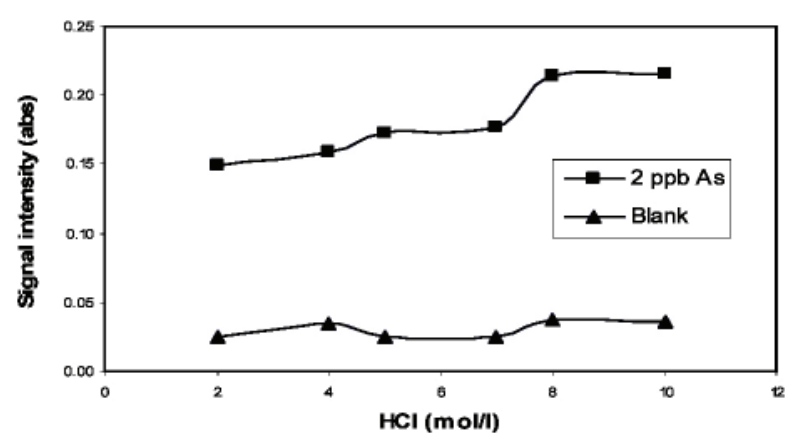

Fig. 2. Influence of $\mathrm{HCl}$ on As standard solution. 


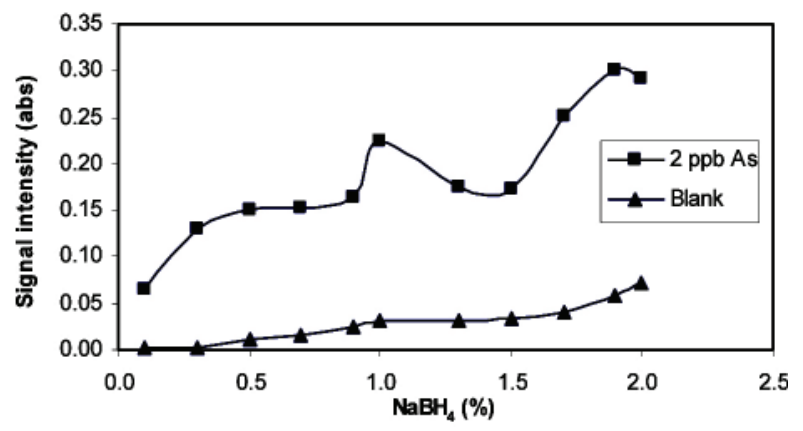

Fig. 3. Influence of $\mathrm{NaBH}_{4}$ on As standard solution.

KI pre-reducion concentration. For determination of total inorganic arsenic before measurement arsenic should be reduced to $\mathrm{As}^{3+}$ form. In this investigation as pre-reductant used potassium iodide with ascorbic acid. $2 ; 3 ; 4 ; 5 ; 6 ; 7 ; 8 ; 9 ; 10 \%$ KI concentrations were prepared and stabilized with $2 \%$ ascorbic acid and tested, using optimized concentration of hydrochloric acid $(8 \mathrm{~mol} / \mathrm{l})$ and sodium tetrahydroborate solutions $\left(0.5 \% \mathrm{NaBH}_{4}\right)$. Signal intensities of $2 \mu \mathrm{g} / \mathrm{l}$ As increased up to $2.5 \%$ with increasing of KI concentration, as shown in Fig. 4. 2.5\% KI concentration was sufficient for quantitative pre-reduction of arsenic and $2.5 \% \mathrm{KI}$ (with $5 \%$ ascorbic acid) was used for analysis.

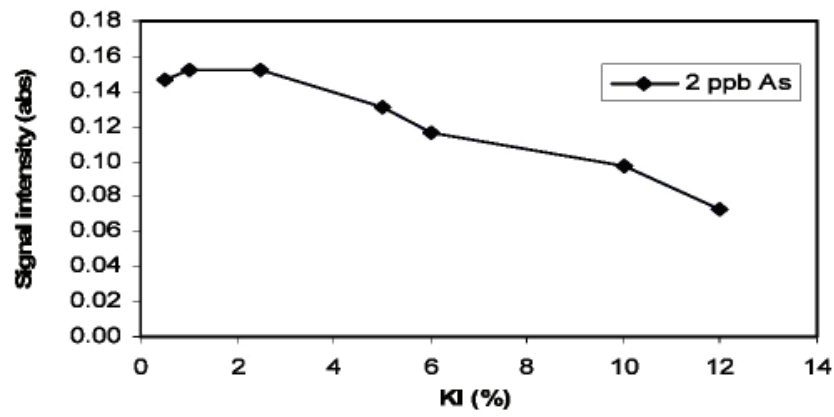

Fig. 4. Influence of KI on As pre-reduction. The influence of different concentrations of KI/ascorbic acid on the reduction efficiency of $2 \mu \mathrm{g} / 1$ arsenic standard solution.

\section{Analytical characteristics of procedure}

The detection limits of optimized HG-AAS method was calculated as the concentration corresponding to 3 times the standard deviation $(3 \sigma)$ of 10 measurements of the method reagent blank and determined as $0.3 \mu \mathrm{g} / \mathrm{l}$ As. Determination limit of the arsenic in solution calculated as the concentration corresponding to 10 times the standard deviation $(10 \sigma)$ of 10 measurements of blank solutions and was $1.0 \mu \mathrm{g} / 1 \mathrm{As}$. Standard solutions were measured with relative standard deviations less than $5 \%$. Compared to the flame 
HG-AAS, the oven HG-AAS gave about two times less background noise. This is shown in Fig. 5.

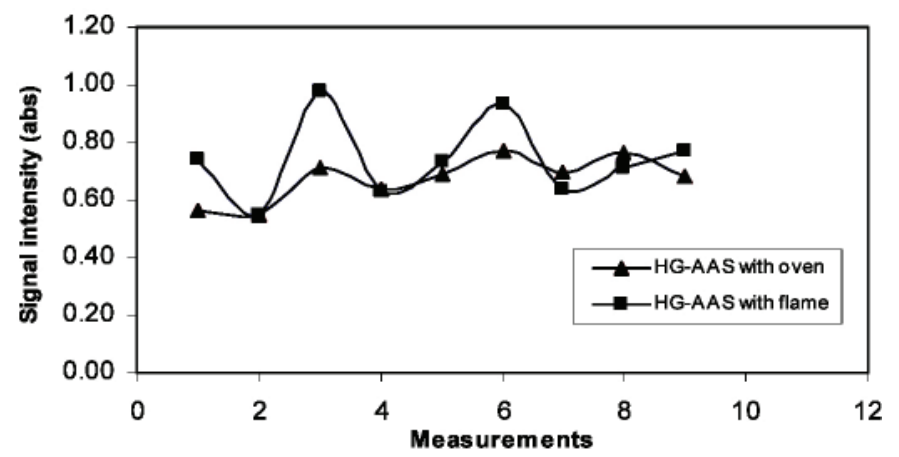

Fig. 5. Comparision of background noise for the oven and flame HG-AAS methods.

The accuracy of the method is confirmed by optimised flame HG-AAS method. As can be seen in Table 3 results of samples, analysed by flame HG-AAS were closer with results, analysed by optimized oven HG-AAS method.

\section{RESULTS AND CONCLUSION}

The results of samples, analyzed for arsenic by optimized HG-AAS with oven and flame HG-AAS are shown in Table 3. The concentration of arsenic in Tuul river, near Gachuurt, Zaisan and Factory (Khan-Uul) districts were in the range $0.9-3.6 \mu \mathrm{g} / 1$. Concentration of arsenic in groundwater and in tap water were around detection limit of methods. The results show, that the concentration of arsenic in selected water samples less than 10 $\mu \mathrm{g} / \mathrm{l}$, as the guideline of Mongolian standard in drinking water for arsenic content. The situation might change in the future and it is important to keep on monitoring the area.

Table 3. Compared results of arsenic in water samples, analysed by flame and oven HG-AAS

Sample

type

Tuul river

Tuul river

Tuul river

Groundwater

Groundwater

Tap water
Location

HG-AAS oven

As, $\mu \mathrm{g} / 1$

HG-AAS flame

As, $\mu \mathrm{g} / 1$

Gachuurt district 0.89

Zaisan district

Factory district

Central part of UB

North part of $U B<0.30$

Central part of UB
2.65

2.91

$<0.30$

0.41
1.20

3.60

0.68

$<0.40$

0.45 
To check the arsenic content, analysed by HG-AAS with the oven samples were analysed by HG -AAS with the flame. The compared results showed good agreement of the flame and oven HG - AAS methods. But the results of arsenic of the flame method were high, because of background signal. In the HG - AAS with oven the absorption cell is heated over the whole surface and temperature can be controlled and much lowered background signal. This gives the possibility for accurate analysis of low concentration of arsenic in water samples by HG-AAS with electrically heated oven.

To confirm the arsenic content in groundwater, sample was analysed by ICP-MS (“Actlabs", Ontario, Canada). The results are shown in Table 4.

Table 4. Results of trace elements $(\mu \mathrm{g} / \mathrm{l})$ in groundwater sample, analysed by ICP-MS

\begin{tabular}{|c|c|c|c|c|c|c|c|c|c|c|c|}
\hline Sample & As & $\mathrm{Ti}$ & V & $\mathrm{Cr}$ & $\mathrm{Fe}$ & Co & $\mathbf{N i}$ & $\mathrm{Cu}$ & $\mathbf{Z n}$ & Mo & Cd \\
\hline $\begin{array}{l}\text { Groundwater/ } \\
\text { Central part of } \\
\text { UB }\end{array}$ & $\underset{0}{\nabla}$ & ț. & $\stackrel{9}{\circ}$ & $\begin{array}{l}n \\
\stackrel{?}{*}\end{array}$ & $\stackrel{\odot}{\mathrm{V}}$ & $\stackrel{\sim}{\stackrel{0}{0}}$ & $\stackrel{m}{\dot{v}}$ & $\ddot{n}$ & $\hat{o}$ & $\stackrel{t}{0}$ & $\stackrel{\overrightarrow{\dot{\rho}}}{\mathrm{v}}$ \\
\hline
\end{tabular}

In this investigation:

$\square$ electrically heated atomizer ETC-60 was installed. Temperature is optimized to $870^{\circ} \mathrm{C}$, this was sufficient for atomization of arsine.

analytical parameters were investigated and optimized as follows: concentration of pre - reductant, $\mathrm{KI}-2.5 \%$, concentration of hydride forming reductant, $\mathrm{NaBH}_{4}-0.5 \%$ and $\mathrm{HCl}-8 \mathrm{~mol} / \mathrm{l}$.

detection limit for determination of arsenic in water sample by optimized HG-AAS with electrically heated atomizer calculated as $0.3 \mu \mathrm{g} / 1$. the accuracy of arsenic result was confirmed by ICP-MS method. this developed method is cheap and silent, because no need for acetylene gas and compressed air.

$\square$ no conclusion can be drawn from the results of water samples except that more investigations are needed and the concentration can be quite different in different wells of Tuul river.

\section{REFERENCES}

1. Dang Q. Hung, Olga Nekrasova, Richard G.Compton. Analytical methods for inorganic arsenic in water: a rewiew. Talanta 64, Oxford, (2004) 269-277.

2. J.A. Plant, D.G. Kinniburgh, P.L.Smedley, F.M. Fordyce, and B.A.Klinck. Arsenic and Selenium. British Geological Survey, Keyworth, Nottingham, UK.

3. Frederic Lime, Tobias Persson. Determination of Total Inorganic Arsenic in the Mekong Delta using HG-AAS with Electrically Heated atomizer. Dept. of Analytical Chemistry s-901 87 Umea University, Sweden, 2002.

4. T. Tsetsegmaa, Ts. Darjaa, D. Dorj. Determination of arsenic in aqua regia digests of geochemical samples of Mongolia, using FAAS and HG-AAS. $3^{\text {rd }}$ International Symposium in chemistry. "Chemistry and Food Safety - 2008", Pp. 57-60, October 02-04, 2008. 
5. W.K. Fletcher. Handbook of Exploration Geochemistry. Volume I. Analytical

6. D. Dorj, Ts. Darjaa, D. Erdenechimeg. Environmental pollution of the heavy metals and toxic chemicals. $3^{\text {rd }}$ International Symposium in chemistry. "Chemistry and Food Safety - 2008", Pp. 8-11. October 02-04, 2008.

7. Jutta Frank, Michael Krachler, William Shotyk. Direct determination of arsenic in acid digests of plant and peat samples using HG-AAS and ICP-SF-MS. Analytica Chimica Acta 530 (2005) 307-316.

8. William B.Nobbins, Park Ridge. Arsenic determination by hydride generation. Varian instrument at work. Number AA-22, 1982.

9. Richard D.Beaty and Jack D. Kerber. Concepts, Instrumentation and Techniques in Atomic Absorption Spectrometry. Second edition. The Perkin-Elmer Corp. Control of analytical interferences. Pp. 37-46 